\title{
Comparative Performance of Fungicides, Biofungicides, and Host Plant Defense Inducers in Suppression of Phytophthora Root Rot in Flowering Dogwood During Simulated Root Flooding Events
}

\author{
Matthew S. Brown, Fulya Baysal-Gurel, ${ }^{\dagger}$ Jason B. Oliver, and Karla M. Addesso \\ Department of Agricultural and Environmental Sciences, College of Agriculture, Otis L. Floyd Nursery Research Center, \\ Tennessee State University, McMinnville, TN 37110
}

\begin{abstract}
During flooding events in nurseries, Phytophthora root rot caused by Phytophthora cinnamomi Rands often causes damage that leads to complete crop loss. In this study, we evaluated the efficacy of fungicides, biofungicides, and host plant defense inducers for preventive and curative control of Phytophthora root rot on flowering dogwood (Cornus florida L.) seedlings exposed to a simulated flood event of 1,3 , or 7 days. In two greenhouse trials, preventive ( 7 days before flooding) or curative (1 day after flooding) drench treatments were applied to dogwood seedlings artificially inoculated with $P$. cinnamomi. The plants were flooded by maintaining standing water for 1,3 , or 7 days. After the trials, plant growth data (total plant weight, root weight, plant height, and plant width) were recorded, and root systems were assessed for disease severity using a scale of 0 to $100 \%$ of roots affected, and subsamples were plated on PARPH-V8 medium to determine the percent recovery of the Phytophthora pathogen. Plants preventively treated with Subdue

Pageant Intrinsic and Segovis treatments also had lower disease severity than the positive control at all flooding durations in trial two, but not trial one. In trial one, preventive and curative treatments of Orkestra Intrinsic had reduced disease severity compared with the positive control at 1 and 3 days of flooding, whereas curative treatments of Empress Intrinsic and Tartan Stressgard also were effective at 1 and 3 days of flooding in trial one. The host plant defense inducers (Aliette 80 WDG, Signature Xtra, and Actigard) were inconsistent and ineffective at reducing disease severity when applied as preventive or curative treatments. Preventive treatments of the biofungicides RootShield Plus $^{+}$and MBI-110 had consistently lower disease severity than the positive control at 1 day of flooding but not 3 or 7 days of flooding. Potentially, growers can use information from this study to manage Phytophthora root rot during flooding or in areas of the nursery that often experience high soil moisture levels.
\end{abstract} MAXX had reduced disease severity relative to the nontreated, inoculated plants (positive control) flooded 1, 3, or 7 days in both trials.

Keywords: soilborne diseases, woody ornamental.

Phytophthora root rot is a devastating disease of ornamental crops (Benson and Von Broembsen 2001; Donahoo and Lamour 2008; Duan et al. 2008; Ferguson and Jeffers 1999). Many ornamental genera, including Acer, Cornus, Juglans, Prunus, Rhododendron, and Quercus, are susceptible to Phytophthora root rot (Zentmyer and Thorn 1967). Root rot diminishes the host root system, thereby limiting the ability of the plant to absorb water and nutrients. Diagnosis of Phytophthora root rot can be difficult, as plants may remain symptomless until late stages of the disease and many of the symptoms of root rot can be confused with other plant diseases (Benson and Von Broembsen 2001). Phytophthora cinnamomi Rands, a common cause of root rot in ornamental nurseries, is established in the southeastern and Pacific Northwest regions of the United States (Benson and Von Broembsen 2001; Duan et al. 2008; Schreier 2013; Zentmyer 1983).

Phytophthora species are oomycetes that overwinter as oospores or chlamydospores in soil, infected roots, and infested crop debris, which supports long-term survival of the pathogen (Mircetich and Zentmyer 1967). Sporangia form in water-filled pores around soil

${ }^{\dagger}$ Corresponding author: F. Baysal-Gurel; fbaysalg@ tnstate.edu

Funding: Partial support for this project was provided by U.S. Department of Agriculture Floriculture and Nursery Research Initiative project number 58-3607-3-984 and a U.S. Department of Agriculture National Institute of Food and Agriculture Evans-Allen grant under award numbers TENX1515-CCOCP, TENX-1520-CCOCP, and TENX-S-1053.

The author(s) declare no conflict of interest.

Accepted for publication 12 February 2019.

(c) 2019 The American Phytopathological Society particles in 4 to $8 \mathrm{~h}$ and release zoospores 20 to $60 \mathrm{~min}$ after the soil is saturated, such as from heavy rainfall or excessive irrigation (Benson and Von Broembsen 2001). Zoospores can then swim a short distance or may be carried long distances by moving water (Duniway 1976).

$P$. cinnamomi prefers high soil moisture levels, and irrigation, runoff, and splashing water often are responsible for transporting the pathogen (Themann et al. 2002; Wilcox and Mircetich 1985). Flooding creates conditions favorable for soilborne pathogen infection by limiting oxygen available to the roots, reducing root health, or increasing zoospore dispersal (Kozlowski 1997; Wilcox and Mircetich 1985).

Previous studies have demonstrated that increased flood duration or frequency enhances the risk of disease associated with soilborne pathogens like Phytophthora species. A combination of flooding and Phytophthora pathogens increased defoliation and disease severity and decreased long-term survival compared with Phytophthora species alone in ornamental cherry trees (Jacobs and Johnson 1996). Phytophthora root rot severity increased with weekly or biweekly flooding compared with monthly or no flooding (de Silva et al. 1999). With longer flooding periods over the range of 0 , $8,12,24$, or $48 \mathrm{~h}$, Phytophthora root rot increased (Wilcox and Mircetich 1985). Plant species differ in their susceptibility to flooding and Phytophthora root rot (Jacobs and Johnson 1996; Wilcox and Mircetich 1985). Even Phytophthora-resistant cultivars or varieties can become susceptible to the disease during extended flooding (Blaker and MacDonald 1981). Other environmental stressors such as drought, heat, and salinity also can increase plant susceptibility to Phytophthora root rot (Blaker and MacDonald 1981; MacDonald 1982, 1991).

Alongside cultural measures to prevent excessive soil moisture, fungicides are often used to provide protection from $P$. cinnamomi as well as prevent the spread of the pathogen throughout the nursery. In previous studies, mefenoxam has been found effective for controlling Phytophthora root rot on woody ornamentals like rhododendrons 
and azaleas (Benson 1985; Benson and Blazich 1989). Fosetyl-Al also has demonstrated activity against Phytophthora root rot, especially in avocados (Benson 1985; Bezuidenhout et al. 1987). Acibenzolar-Smethyl and mefenoxam increased survival of pepper plants exposed to flooding, while pyaclostrobin plus boscalid reduced disease severity on flooded redbuds and tulip poplar trees (Addesso et al. 2018; Matheron and Porchas 2002).

Some fungicides, such as strobilurins and triazoles, as well as biofungicides, increase stress tolerance in plants (Abdul Jaleel et al. 2008; Harman 2006; Herms et al. 2002; Kloepper et al. 2004; Venancio et al. 2003). Fungicides that increase antioxidant activity likely provide enhanced tolerance to stress factors such as flooding, drought, low and high temperature extremes, salinity, ultraviolet radiation, and pollutants (Abdul Jaleel et al. 2008; Han et al. 2012; Kraus et al. 1995; Lin et al. 2006; Wu and Tiedemann 2001). Fungicides also may boost the immune response of the host plant to pathogens in addition to providing direct fungicidal activity (Conrath et al. 2006; Harman 2006; Herms et al. 2002; Kloepper et al. 2004). Fungicides that increase host stress tolerance may be especially effective when plant hosts are simultaneously affected by disease and environmental stress.

Since Phytophthora root rot often is associated with flooding, understanding effective management techniques for Phytophthora pathogens within the context of flooding is important. However, research evaluating treatment options for flooded plants is limited (Addesso et al. 2018; Matheron and Porchas 2002). Because flooding is unpredictable, exploring effective curative control of Phytophthora species after flood events is also important for nursery producers. The objective of this study was to evaluate fungicides, biofungicides, or host plant defense inducers for preventive and curative control of $P$. cinnamomi on flowering dogwood seedlings (C. florida L.) exposed to a simulated root flooding event of 1, 3, or 7 days. This study can provide nursery producers with potential treatments for woody ornamentals exposed to flooding, which are subsequently at greater risk of Phytophthora root rot development.

\section{Materials and Methods}

Study location and design. The study was conducted in a greenhouse at the Tennessee State University Otis L. Floyd Nursery Research Center in McMinnville, Tennessee. Flowering dogwood cultivar Cherokee Princess seeds were stratified by placing the seeds in clear zip-top plastic bags with moistened potting substrate (Morton's Grow Mix 2: Canadian sphagnum peat [60\%], vermiculite [20\%], and perlite [20\%], with an average substrate bulk density reported by the manufacturer of $144 \mathrm{~kg} / \mathrm{m}^{3}$; Morton's Horticultural Products, McMinnville, TN) at $5{ }^{\circ} \mathrm{C}$ for 3 months to satisfy physiological dormancy. Seeds were transplanted on 3 April 2017 (trial one) and 20 January 2018 (trial two) and grown in 10.2-cm pots containing potting substrate (Morton's Grow Mix 2). Seedlings were watered for 2 min daily with overhead irrigation and hand watered as necessary. Seedlings were fertilized with Miracle-Gro Water Soluble All Purpose Plant Food (Scott's Miracle-Gro Co., Marysville, $\mathrm{OH})$ at a rate of $3.8 \mathrm{~g} /$ liter ( $22 \mathrm{ml}$ solution/container) on 9 June 2017 (trial one) and 9 April 2018 (trial two). In trial one, plants were treated on 21 June and 3 and 20 July 2017 for dogwood powdery mildew (Erysiphe pulchra [Cooke \& Peck] U. Braun \& S. Takam) with foliar sprays of Concert II 4.3SE (2.67 ml product/liter, chlorothalonil plus propiconazole; Syngenta International AG, Basel, Switzerland). Plants did not show symptoms of powdery mildew in trial two.

Seven fungicides, three host plant defense inducers, and two biofungicides were evaluated for their ability to control $P$. cinnamomi on flooded dogwood seedlings under greenhouse conditions (Table 1). The trials took place from 3 to 31 July 2017 (trial one) and from 30 April to 1 June 2018 (trial two) on 3- to 4-month-old seedlings using a randomized complete block design with five replications. Treatments were made as a preventive drench application 7 days before flooding or as a curative drench application $24 \mathrm{~h}$ after flooding, except for Actigard 50WG (Actigard), MBI-110, and RootShield Plus $^{+}$WP (RootShield Plus ${ }^{+}$), which were applied only as preventive drench applications (Table 1). All treatments were applied once according to the label directions at the highest labeled rates with $50 \mathrm{ml}$ of fungicide solution/pot (Table 1). Control treatments included nontreated, inoculated plants (positive control) and nontreated, noninoculated plants (negative control), and these plants received $50 \mathrm{ml}$ of water/pot. Some products are not currently labeled for commercial nursery use but were provided by manufacturers for experimentation and potential future changes in label registrations.

Isolate FBG201510 of $P$. cinnamomi (GenBank accession MK099813) was obtained from the culture collection of Dr. Fulya Baysal-Gurel at the Tennessee State University Otis L. Floyd Nursery Research Center. The $P$. cinnamomi specimen was originally isolated from a diseased flowering dogwood (C. florida 'Cherokee Princess') root and maintained on V8 agar medium. Before this study, dogwood plant roots (Cherokee Princess) were inoculated with the $P$. cinnamomi culture, and the pathogen was subsequently reisolated from the diseased roots to confirm virulence. For the

Table 1. Fungicides, biofungicides, and host plant defense inducers used in this study

\begin{tabular}{|c|c|c|c|c|}
\hline \multirow[b]{2}{*}{ Treatment $^{y}$} & \multicolumn{2}{|c|}{ Application rate } & \multirow[b]{2}{*}{ Product group } & \multirow[b]{2}{*}{ Manufacturer $^{2}$} \\
\hline & $\overline{\mathrm{ml} / \mathrm{liter}}$ & $\overline{\text { g/liter }}$ & & \\
\hline Actigard 50WG & & 0.30 & Host plant defense inducer & Syngenta \\
\hline Aliette 80 WDG & & 3.74 & Host plant defense inducer & Bayer \\
\hline Empress Intrinsic & 0.47 & & Strobilurin & BASF \\
\hline Interface Stressgard & 6.25 & & Strobilurin + dicarboximide & Bayer \\
\hline MBI-110 & 10.00 & & Biofungicide & Marrone \\
\hline Orkestra Intrinsic & 0.78 & & $\begin{array}{l}\text { Strobilurin }+ \text { succinate } \\
\quad \text { dehydrogenase inhibitor }\end{array}$ & BASF \\
\hline Pageant Intrinsic & & 1.35 & $\begin{array}{l}\text { Strobilurin }+ \text { succinate } \\
\quad \text { dehydrogenase inhibitor }\end{array}$ & BASF \\
\hline RootShield Plus ${ }^{+}$WP & & 0.60 & Biofungicide & BioWorks \\
\hline Segovis & 0.25 & & Piperidinyl-thiazole isoxazoline & Syngenta \\
\hline Signature Xtra Stressgard & & 5.99 & Host plant defense inducer & Bayer \\
\hline Subdue MAXX & 0.16 & & Phenylamide & Syngenta \\
\hline Tartan Stressgard & 3.12 & & Strobilurin + triazole & Bayer \\
\hline
\end{tabular}

y Active ingredients (\% A.I.) are as follows: Actigard = acibenzolar-S-methyl $(50 \%)$; Aliette $=$ aluminum tris $(0$-ethyl phosphanate) $(80 \%)$; Empress Intrinsic $=$ pyraclostrobin (23.3\%); Interface Stressgard = trifloxystrobin $(1.44 \%)+$ iprodione $(23.1 \%)$; MBI-110 = Bacillus amyloliquefaciens strain F727; Orkestra Intrinsic $=$ pyraclostrobin $(21.26 \%)+$ fluxapyroxad $(21.26 \%) ;$ Pageant Intrinsic $=$ pyraclostrobin $(12.8 \%)+$ boscalid $(25.2 \%)$; RootShield Plus ${ }^{+}=$Trichoderma harzianum Rifai strain T-22 (1.15\%) + T. virens strain G-41 (0.61\%); Segovis = oxathiapiprolin (18.7\%); Signature Xtra Stressgard = aluminum tris $(0$-ethyl phosphanate) $(60 \%)$; Subdue MAXX = mefenoxam $(22 \%)$; and Tartan Stressgard $=$ trifloxystrobin $(4.17 \%)+$ triadimefon $(20.86 \%)$.

${ }^{\mathrm{z}}$ Manufacturer locations are as follows: Syngenta International AG (Basel, Switzerland), Bayer AG (Monheim an Rhein, Germany), BASF Corporation (Florham Park, NJ), Marrone Bio Innovations Inc. (Davis, CA), and BioWorks Inc. (Victor, NY). 
preparation of inoculum, $25 \mathrm{~g}$ of rice and $22 \mathrm{ml}$ of deionized water were autoclaved for $30 \mathrm{~min}$. Six $1-\mathrm{cm}^{2}$ plugs of $P$. cinnamomi were mixed with cooked rice and allowed to colonize rice grains for 2 weeks (Holmes and Benson 1994). Flowering dogwood seedlings were artificially inoculated by burying two $P$. cinnamomi-colonized rice grains in the potting substrate on opposite sides of the seedling 3 days before flooding. Sterilized rice grains were used for negative control plants.

All treatments, including the positive and negative controls, were flooded for 1, 3, or 7 days using tap water. Flooding conditions were imposed by enclosing containers in clear zip-top plastic bags and maintaining standing water. Before the trials, substrate temperatures of five containers were taken using an infrared temperature meter/soil temperature meter in probe measurement mode (Spectrum Technologies Inc., East Plainfield, IL) with and without the clear zip-top plastic bag, to ensure the plants were not heated by the experimental flooding technique and the temperatures were similar under sunny greenhouse conditions (i.e., $26.1^{\circ} \mathrm{C}$ with the plastic bag and $25.4^{\circ} \mathrm{C}$ without the plastic bag). Throughout the flooding period, each plant was hand watered daily, as necessary, to ensure the roots remained submerged. Substrate moisture was recorded with a FieldScout TDR100 soil moisture meter (Spectrum Technologies, Aurora, IL) for all nontreated, noninoculated control plants, and the average volumetric water content of the container substrate was $66 \%$. After flooding for 1,3 , or 7 days, the containers were allowed to drain. Plants were hand watered until all plants were drained and then watered for 2 min daily with overhead irrigation.

Data recording. After a period of time to allow disease development after the last flooding period (14 to 18 days), plants were removed from the greenhouse, and the roots were washed to remove debris. Plant height and plant width (average of the widest part from leaf tip to leaf tip and the width perpendicular to the widest part) were recorded before and after the trials. Plant total fresh weight, root fresh weight (roots were cut from the plant at the base of the root collar), and plant mortality were recorded at the end of the trials. In addition, the severity of Phytophthora root rot was assessed visually, using a scale of 0 to $100 \%$ of the total root system affected at the end of the trials.

Phytophthora infection was determined by plating five randomly selected root samples ( $15 \mathrm{~mm}$ long) from the root tips of each plant (five replications per treatment) on PARPH-V8 medium (Ferguson and Jeffers 1999). The presence or absence of Phytophthora growth surrounding each root sample was recorded after 2 weeks. For PARPH-V8-selective medium, $0.50 \mathrm{~g}$ of $\mathrm{CaCO}_{3}$ (98\%; Acros Organics, Geel, Belgium) was added to $50 \mathrm{ml}$ of V8 juice (Campbell's Soup Co., Camden, NJ) and centrifuged for $10 \mathrm{~min}$ at 7,000 rpm. The buffered and clarified V8 juice was added to $450 \mathrm{ml}$ of deionized water, along with $7.5 \mathrm{~g}$ of agar (Sigma-Aldrich, St. Louis, MO), and autoclaved for $15 \mathrm{~min}$. Afterward, $500 \mu \mathrm{l}$ of the fungicide and the following antibiotics were added to the medium: pentachloronitrobenzene (PCNB) (99\% [GC]; $0.63 \mathrm{~g} / 50 \mathrm{ml}$ of ethanol; Sigma-Aldrich), ampicillin (1.25 g/50 ml of ethanol; Sigma-Aldrich), rifampicin $(0.05 \mathrm{~g} / 50 \mathrm{ml}$ of ethanol; Sigma-Aldrich), pimaricin (2.5\%; MP Biomedicals, Santa Ana, CA), and hymexazol (250 mg/50 ml of sterilized water; Sigma-Aldrich) (Ferguson and Jeffers 1999; Jeffers and Martin 1986).

Trichoderma colonization in the RootShield Plus ${ }^{+}$-treated plants was determined using dilution plating on Trichoderma-selective medium. For Trichoderma-selective medium, $0.1 \mathrm{~g}$ of $\mathrm{MgSO}_{4}-7 \mathrm{H}_{2} \mathrm{O}$ (Sigma-Aldrich), $0.45 \mathrm{~g}$ of $\mathrm{KH}_{2} \mathrm{PO}_{4}$ (Sigma-Aldrich), $0.5 \mathrm{~g}$ of $\mathrm{NH}_{4} \mathrm{NO}_{3}$ (Alfa Aesar, Tewksbury, MA), $0.075 \mathrm{~g}$ of $\mathrm{KCl}$ (Sigma-Aldrich), $1.5 \mathrm{~g}$ of dextrose (VWR, Radnor, PA), $0.01 \mathrm{~g}$ of $\mathrm{FeSO}_{4}-7 \mathrm{H}_{2} \mathrm{O}$ (VWR), $0.01 \mathrm{~g}$ of $\mathrm{MnSO}_{4}-\mathrm{H}_{2} \mathrm{O}$ (Fisher Scientific, Pittsburgh, PA), $0.01 \mathrm{~g}$ of $\mathrm{ZnSO}_{4}-7 \mathrm{H}_{2} \mathrm{O}$ (Fisher Scientific), $0.015 \mathrm{~g}$ of rose Bengal (Fisher Scientific), $10.0 \mathrm{~g}$ of agar (Sigma-Aldrich), and $500 \mathrm{ml}$ of deionized water were autoclaved for 15 min (Chung and Hoitink 1990). Afterward, the fungicides and antibiotics, $0.05 \mathrm{~g}$ of PCNB (99\% [GC]), $5 \mu l$ of Subdue MAXX (Syngenta International AG), $0.025 \mathrm{~g}$ chloramphenicol (Sigma-Aldrich), and $0.025 \mathrm{~g}$ streptomycin sulfate (Acros Organics) were added to the medium. For each plant, a 1-g root sample and $10 \mathrm{ml}$ of sterilized deionized water were ultrasonicated (5.7 liters of Fisherbrand M-Series Mechanical Ultrasonic Cleaning Bath; Thermo Fisher Scientific Inc., Waltham, MA) for $3 \mathrm{~min}$ and then agitated with a shaker (Fisherbrand Incubating Mini-Shaker; Thermo Fisher Scientific Inc.) at $250 \mathrm{rpm}$ for $30 \mathrm{~min}$ at room temperature. The particles were then allowed to settle for $30 \mathrm{~min}$. Dilutions of $10^{-2}$ and $10^{-4}$ were prepared and spreadplated using glass beads (3-mm solid glass beads; Walter Stern Inc., Manorhaven, NY), as well as $100 \mu \mathrm{l}$ of the undiluted sample. The number of Trichoderma colonies on plates were recorded after incubation for 10 days at room temperature. The number of colony forming units per gram of root sample was calculated from the plate counts, the dilution factor, and the plated volume.

Data analysis. Plant height, plant width, total fresh weight, root fresh weight, disease severity, and percent recovery of $P$. cinnamomi from root samples were compared among preventively or curatively applied treatments. Plant growth data (plant height, plant width, fresh plant weight, and fresh root weight) were analyzed using one-way analysis of variance with SAS software, and means were separated using Fisher's least significant difference test $(\alpha=0.05)$ (Proc GLM). The percentage of roots affected by the Phytophthora pathogen (disease severity) were analyzed using a generalized linear mixed model (GLMM) in SAS with a logit link and assuming a beta distribution, and means were separated by least squares means $(\alpha=0.05)$ (Proc GLIMMIX). Plants with disease severities of 0 or $100 \%$ were changed to 0.01 and $99.99 \%$, respectively, to meet the assumptions of the GLMM. The percent recovery of $P$. cinnamomi from root samples was analyzed using logistic regression in SAS with a logit link and binomial distribution, and means were separated by least squares means $(\alpha=0.05)$ (Proc GENMOD). Treatments for which the percent recovery of $P$. cinnamomi from root samples was 0 to $5 \%$ had one replicate randomly changed to 0.5 to $4.5 \%$ to meet the assumptions of Proc GENMOD. The numbers of Trichoderma colonies growing on Trichoderma-selective media were compared between flood durations with a generalized linear interactive model using a negative binomial distribution and a log link, and means were separated by least squares means $(\alpha=0.05)$ (Proc GENMOD) (Agresti 2002).

\section{Results}

Plant mortality increased with higher disease severity (Fig. 1). When disease severity was $<60 \%$, seedling mortality was 0 to $40 \%$, but disease severity $>60 \%$ was associated with seedling mortality of 20 to $80 \%$ (Fig. 1). Throughout both trials, 25\% of the positive control plants died, whereas none of the negative controls died. With increased flooding duration, there was increased plant mortality (i.e., $1.7,15.7$, and $34.8 \%$ at 1,3 , and 7 days, respectively).

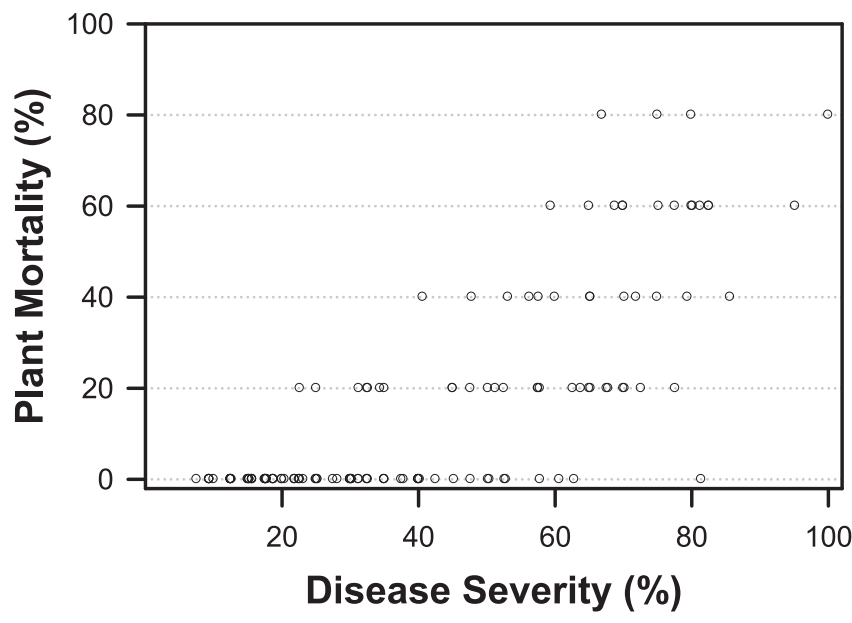

Fig. 1. Plant mortality in relation to mean disease severity. Each point represents one treatment $(n=138)$ with five replicates (trials one and two). Plant mortality is the percentage of flowering dogwood plants (or replicates) that died within a treatment. 
The positive control had the highest disease severity at all flooding durations in both trials, except at 7 days of flooding in trial two (Figs. 2 and 3), while the positive control plants also had the highest percent recovery of $P$. cinnamomi from root samples at all flooding durations in trial one and at 7 days of flooding in trial two (Tables 2 and 3). The negative control plants had lower disease severity compared with the positive control plants at 3 days of flooding in the preventive and curative treatment analysis and 7 days of flooding only in the preventive treatment analysis in trial one and all flooding durations in trial two (Figs. 2 and 3), as well as a lower percent recovery of P. cinnamomi from root samples at all flooding durations in both trials (Tables 2 and 3 ). The positive control had increased disease severity with increased flooding duration (trial one: $P=0.0013$; trial two: $P=0.0244$ ), whereas there were no differences detected in disease severity in the negative control among flooding durations (trial one: $P=$ 0.8375; trial two: $P=0.1458$; Figs. 2 and 3).
Preventive fungicide treatments. There were no significant interactions between flooding duration and preventive treatments for plant height (trial one: $P=0.7197$; trial two: $P=0.6306$ ), plant width (trial one: $P=0.8352$; trial two: $P=0.7195$ ), plant weight (trial one: $P=0.0885$; trial two: $P=0.9332$ ), or root weight (trial one: $P=$ 0.2219; trial two: $P=0.9304$ ), so the flooding duration data were pooled. No differences were detected between preventive treatments and the positive control for plant height, plant width, plant weight, or root weight in trial one (Table 4). In trial two, Segovis- or Subdue MAXX-treated plants were wider than the positive control plants (Table 4). Plants preventively treated with Empress Intrinsic (Empress), Orkestra Intrinsic (Orkestra), Pageant Intrinsic (Pageant), Segovis, Signature Xtra Stressgard (Signature Xtra), and Subdue MAXX weighed more than positive control plants (trial two, Table 4). Orkestra, Segovis, and Subdue MAXX treatments had a higher root weight than the positive control (trial two, Table 4).

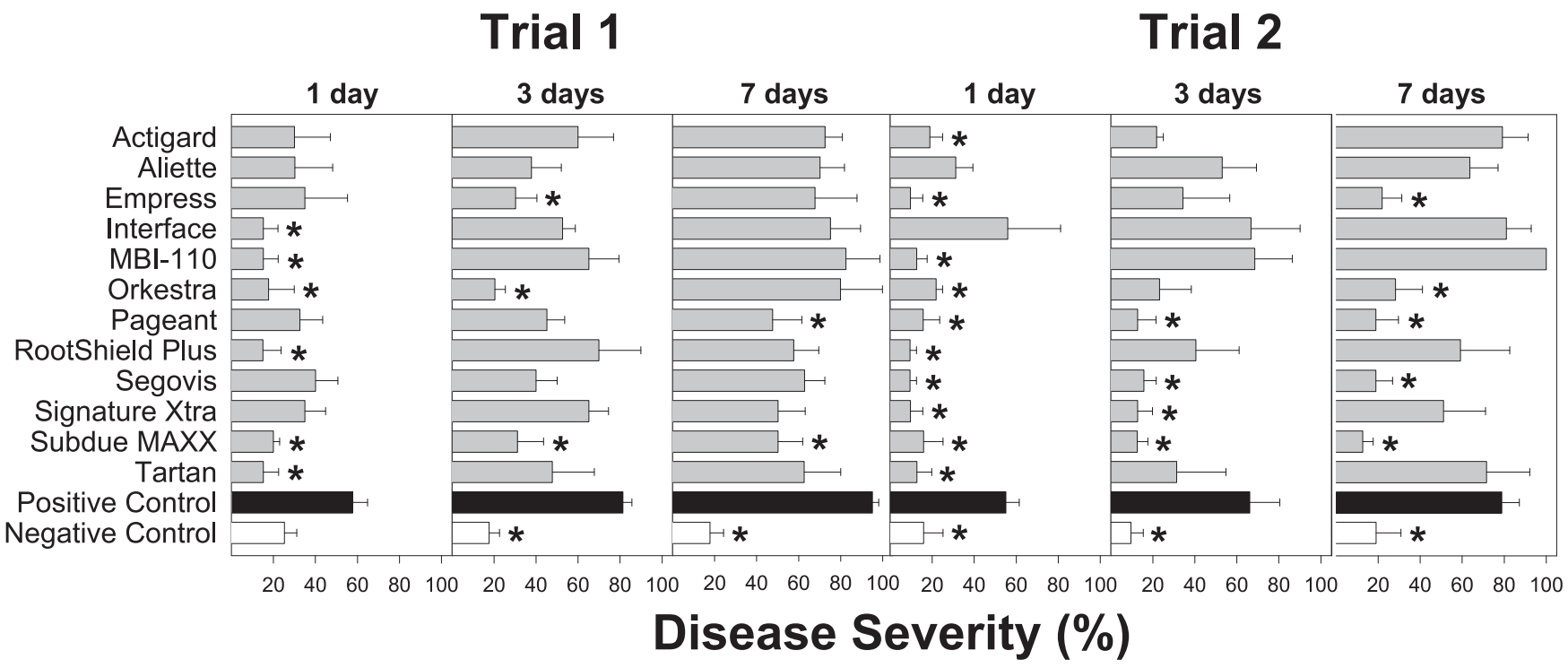

Fig. 2. Disease severity (mean \pm SE) of plants treated preventively with fungicides, biofungicides, or host plant defense inducers at 1,3 , or 7 days of flooding in trials 1 (left) and 2 (right). For root rot disease severity, each plant was evaluated using a scale of 0 to $100 \%$ of roots affected. Control treatments included the nontreated, inoculated plants (positive control; black bars) and nontreated, noninoculated plants (negative control; white bars). Asterisks beside bars represent significant differences in disease severity within a flooding duration compared with the positive control ( $\alpha=0.05$, least squares means).

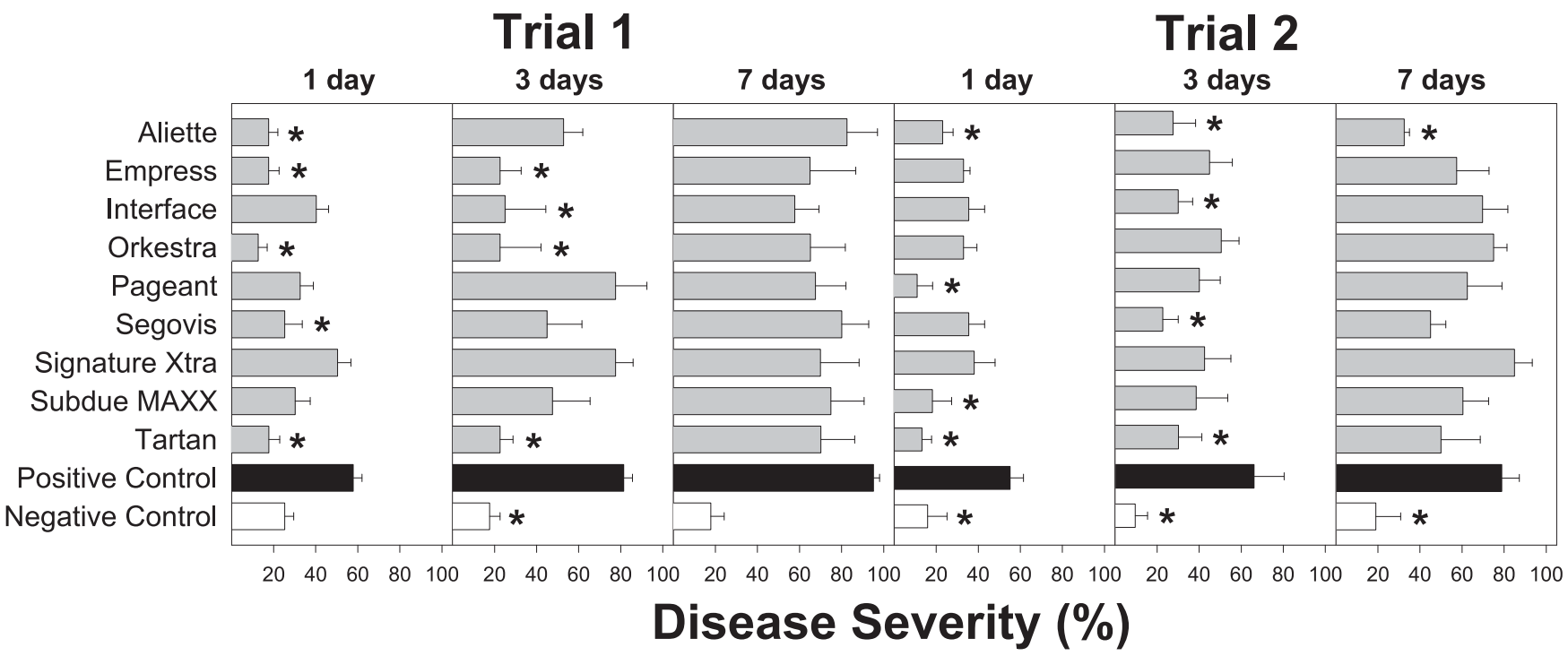

Fig. 3. Disease severity (mean $\pm \mathrm{SE}$ ) of plants treated curatively with fungicides or host plant defense inducers at 1, 3, or 7 days of flooding in trials 1 (left) and 2 (right). For root rot disease severity, each plant was evaluated using a scale of 0 to $100 \%$ of roots affected. Control treatments included the nontreated, inoculated plants (positive control; black bars) and nontreated, noninoculated plants (negative control; white bars). Asterisks beside bars represent significant differences in disease severity within a flooding duration compared with the positive control ( $\alpha=0.05$, least squares means). 
In trial one, interactions between preventive treatments and flooding duration in disease severity were significant $(P=0.0020)$, so the disease severity data were analyzed separately for each flood duration. Subdue MAXX was the only preventive fungicide treatment with a lower disease severity than the positive control at all flooding durations (Fig. 2). Preventive applications of Orkestra reduced disease severity compared with the positive control at 1 and 3 days of flooding (Fig. 2). Seedlings preventively treated with Interface Stressgard (Interface), MBI-110, RootShield Plus ${ }^{+}$, or Tartan Stressgard (Tartan) had lower disease severity than the positive control plants flooded 1 day (Fig. 2). Empress preventive treatments had lower disease severity than the positive control seedlings at 3 days of flooding (Fig. 2), while preventive treatments of Pageant had lower disease severity than positive control plants flooded for 7 days (Fig. 2).
As in trial one, interactions between preventive treatments and flooding duration were significant for disease severity data in trial two $(P=0.0152)$. Consistent with trial one, Subdue MAXXtreated plants had lower disease severity than the positive control plants at all flooding durations (Fig. 2). The Pageant and Segovis treatments also had lower disease severity in trial two at all flooding durations, but neither fungicide was effective in trial one, except Pageant at 7 days of flooding (Fig. 2). Plants preventively treated with Empress or Orkestra had lower disease severity than the positive control at 1 and 7 days of flooding (Fig. 2), and Signature Xtra-treated plants had lower disease severity than the positive control at 1 and 3 days of flooding (Fig. 2). Preventive applications of Actigard, MBI-110, RootShield Plus ${ }^{+}$, or Tartan had reduced disease severity compared with the positive control at 1 day of flooding (Fig. 2).

Table 2. Percent recovery of Phytophthora cinnamomi from root samples (mean \pm SE) treated with preventively applied fungicides, biofungicides, or host plant defense inducers

\begin{tabular}{|c|c|c|c|c|c|c|}
\hline \multirow[b]{3}{*}{ Treatment } & \multicolumn{6}{|c|}{ Percent recovery of $P$. cinnamomi from root samples at different flood durations ${ }^{\mathrm{x}}$} \\
\hline & \multicolumn{3}{|c|}{ Trial 1} & \multicolumn{3}{|c|}{ Trial 2} \\
\hline & 1 day & 3 days & 7 days & 1 day & 3 days & 7 days \\
\hline Actigard & $0.16 \pm 0.12 \mathrm{abc}^{\mathrm{y}}$ & $0.32 \pm 0.16 \mathrm{a}$ & $0.36 \pm 0.16 \mathrm{bcd}$ & $0.48 \pm 0.18 \mathrm{abc}$ & $0.20 \pm 0.19 \mathrm{e}$ & $0.60 \pm 0.25 \mathrm{abc}$ \\
\hline Aliette & $0.04 \pm 0.04 \mathrm{c}$ & $0.12 \pm 0.12 \mathrm{ab}$ & $0.00 \pm 0.00 \mathrm{e}$ & $0.80 \pm 0.10 \mathrm{a}$ & $0.52 \pm 0.24 \mathrm{bcd}$ & $0.80 \pm 0.10 a b$ \\
\hline Empress & $0.28 \pm 0.20 \mathrm{ab}$ & $0.08 \pm 0.05 \mathrm{~b}$ & $0.08 \pm 0.08 \mathrm{e}$ & $0.68 \pm 0.08 \mathrm{ab}$ & $0.32 \pm 0.20 \mathrm{cde}$ & $0.52 \pm 0.21 \mathrm{bc}$ \\
\hline Interface & $0.08 \pm 0.05 \mathrm{bc}$ & $0.04 \pm 0.04 \mathrm{~b}$ & $0.48 \pm 0.21 \mathrm{ab}$ & $0.80 \pm 0.10 \mathrm{a}$ & $1.00 \pm 0.00 \mathrm{a}$ & $0.44 \pm 0.22 \mathrm{c}$ \\
\hline MBI-110 & $0.24 \pm 0.19 a b c$ & $0.00 \pm 0.00 \mathrm{~b}$ & $0.40 \pm 0.21 b c$ & $1.00 \pm 0.00 \mathrm{a}$ & $0.60 \pm 0.13 a b c$ & $0.64 \pm 0.15 \mathrm{abc}$ \\
\hline Orkestra & $0.04 \pm 0.04 \mathrm{c}$ & $0.16 \pm 0.16 \mathrm{ab}$ & $0.20 \pm 0.16 \mathrm{cde}$ & $0.36 \pm 0.22 \mathrm{~cd}$ & $0.60 \pm 0.25 a b c$ & $0.56 \pm 0.24 \mathrm{bc}$ \\
\hline Pageant & $0.00 \pm 0.00 \mathrm{c}$ & $0.04 \pm 0.04 \mathrm{~b}$ & $0.12 \pm 0.08 \mathrm{de}$ & $0.44 \pm 0.26 \mathrm{bcd}$ & $0.44 \pm 0.26$ b-e & $0.44 \pm 0.22 \mathrm{c}$ \\
\hline RootShield Plus ${ }^{+}$ & $0.08 \pm 0.05 \mathrm{bc}$ & $0.36 \pm 0.12 \mathrm{a}$ & $0.20 \pm 0.13 \mathrm{cde}$ & $0.44 \pm 0.26 \mathrm{ab}$ & $0.80 \pm 0.05 \mathrm{a}$ & $0.76 \pm 0.15 \mathrm{ab}$ \\
\hline Segovis & $0.04 \pm 0.04 \mathrm{c}$ & $0.16 \pm 0.12 \mathrm{ab}$ & $0.00 \pm 0.00 \mathrm{e}$ & $0.40 \pm 0.24 \mathrm{bcd}$ & $0.52 \pm 0.22 \mathrm{bcd}$ & $0.80 \pm 0.10 a b$ \\
\hline Signature Xtra & $0.16 \pm 0.12 a b c$ & $0.12 \pm 0.08 \mathrm{ab}$ & $0.08 \pm 0.08 \mathrm{e}$ & $0.28 \pm 0.22 \mathrm{~d}$ & $0.72 \pm 0.14 \mathrm{abc}$ & $0.72 \pm 0.10 \mathrm{ab}$ \\
\hline Subdue MAXX & $0.04 \pm 0.04 \mathrm{c}$ & $0.04 \pm 0.04 \mathrm{~b}$ & $0.24 \pm 0.15 \mathrm{~b}-\mathrm{e}$ & $0.40 \pm 0.29 \mathrm{bcd}$ & $0.24 \pm 0.22 \mathrm{de}$ & $0.60 \pm 0.24 \mathrm{abc}$ \\
\hline Tartan & $0.00 \pm 0.00 \mathrm{c}$ & $0.08 \pm 0.08 \mathrm{~b}$ & $0.08 \pm 0.08 \mathrm{e}$ & $0.36 \pm 0.26 \mathrm{~cd}$ & $1.00 \pm 0.00 \mathrm{a}$ & $0.84 \pm 0.05 \mathrm{a}$ \\
\hline Negative control $^{\mathrm{Z}}$ & $0.00 \pm 0.00 \mathrm{c}$ & $0.00 \pm 0.00 \mathrm{~b}$ & $0.00 \pm 0.00 \mathrm{e}$ & $0.00 \pm 0.00 \mathrm{e}$ & $0.00 \pm 0.00 \mathrm{f}$ & $0.00 \pm 0.00 \mathrm{~d}$ \\
\hline Positive control $^{\mathrm{z}}$ & $0.40 \pm 0.09 \mathrm{a}$ & $0.36 \pm 0.08 \mathrm{a}$ & $0.72 \pm 0.12 \mathrm{a}$ & $0.48 \pm 0.20 \mathrm{abc}$ & $0.92 \pm 0.05 \mathrm{a}$ & $0.88 \pm 0.10 \mathrm{a}$ \\
\hline$x^{2}$ & 39.82 & 39.60 & 81.95 & 89.14 & 109.52 & 81.34 \\
\hline Degrees of freedom & 13 & 13 & 13 & 13 & 13 & 13 \\
\hline$P$ value & 0.0001 & 0.0002 & $<0.0001$ & $<0.0001$ & $<0.0001$ & $<0.0001$ \\
\hline
\end{tabular}

${ }^{\mathrm{x}}$ For each plant (five replications per treatment), five randomly selected flowering dogwood root samples were plated on PARPH-V8 Phytophthora-selective medium to determine the percent recovery of $P$. cinnamomi from root samples.

${ }^{y}$ Treatment means within columns followed by different letters were significantly different $(\alpha=0.05)$.

${ }^{\mathrm{z}}$ Control treatments included the nontreated, inoculated plants (positive control) and nontreated, noninoculated plants (negative control).

Table 3. Percent recovery of Phytophthora cinnamomi from root samples (mean \pm SE) treated with curatively applied fungicides or host plant defense inducers

\begin{tabular}{|c|c|c|c|c|c|c|}
\hline \multirow[b]{3}{*}{ Treatment } & \multicolumn{6}{|c|}{ Percent recovery of $P$. cinnamomi from root samples at different flood durations ${ }^{\mathrm{x}}$} \\
\hline & \multicolumn{3}{|c|}{ Trial 1} & \multicolumn{3}{|c|}{ Trial 2} \\
\hline & 1 day & 3 days & 7 days & 1 day & 3 days & 7 days \\
\hline Aliette & $0.08 \pm 0.05 \mathrm{~b}^{\mathrm{y}}$ & $0.16 \pm 0.12 \mathrm{abc}$ & $0.28 \pm 0.12 \mathrm{~cd}$ & $0.28 \pm 0.07 \mathrm{bc}^{\mathrm{y}}$ & $0.64 \pm 0.10 \mathrm{ab}$ & $0.28 \pm 0.10 \mathrm{cde}$ \\
\hline Empress & $0.08 \pm 0.08 \mathrm{~b}$ & $0.04 \pm 0.04 \mathrm{c}$ & $0.56 \pm 0.23 \mathrm{ab}$ & $0.12 \pm 0.08 \mathrm{bc}$ & $0.04 \pm 0.04 \mathrm{~d}$ & $0.20 \pm 0.08 \mathrm{de}$ \\
\hline Interface & $0.04 \pm 0.04 \mathrm{~b}$ & $0.16 \pm 0.16 \mathrm{abc}$ & $0.12 \pm 0.05 \mathrm{de}$ & $0.16 \pm 0.05 b c$ & $0.32 \pm 0.08 \mathrm{~cd}$ & $0.28 \pm 0.12$ cde \\
\hline Orkestra & $0.04 \pm 0.04 \mathrm{~b}$ & $0.28 \pm 0.15 \mathrm{ab}$ & $0.60 \pm 0.21 \mathrm{ab}$ & $0.28 \pm 0.12 b c$ & $0.16 \pm 0.04 \mathrm{~d}$ & $0.16 \pm 0.08 \mathrm{de}$ \\
\hline Pageant & $0.08 \pm 0.05 \mathrm{~b}$ & $0.28 \pm 0.15 \mathrm{ab}$ & $0.36 \pm 0.19 \mathrm{bcd}$ & $0.32 \pm 0.09 \mathrm{bc}$ & $0.36 \pm 0.07 \mathrm{~cd}$ & $0.36 \pm 0.13 \mathrm{cde}$ \\
\hline Segovis & $0.00 \pm 0.00 \mathrm{~b}$ & $0.32 \pm 0.21 \mathrm{a}$ & $0.32 \pm 0.21 \mathrm{bcd}$ & $0.32 \pm 0.07 \mathrm{bc}$ & $0.28 \pm 0.05 \mathrm{~cd}$ & $0.52 \pm 0.18 b c$ \\
\hline Signature Xtra & $0.04 \pm 0.04 \mathrm{~b}$ & $0.08 \pm 0.08 \mathrm{bc}$ & $0.32 \pm 0.15 \mathrm{bcd}$ & $0.28 \pm 0.09 \mathrm{bc}$ & $0.36 \pm 0.10 \mathrm{~cd}$ & $0.48 \pm 0.12 \mathrm{bcd}$ \\
\hline Subdue MAXX & $0.08 \pm 0.05 b$ & $0.08 \pm 0.05 \mathrm{bc}$ & $0.36 \pm 0.18 \mathrm{bcd}$ & $0.24 \pm 0.07 \mathrm{bc}$ & $0.52 \pm 0.12 b c$ & $0.72 \pm 0.10 \mathrm{ab}$ \\
\hline Tartan & $0.04 \pm 0.04 \mathrm{~b}$ & $0.12 \pm 0.08 \mathrm{abc}$ & $0.44 \pm 0.20 \mathrm{bc}$ & $0.36 \pm 0.12 b$ & $0.36 \pm 0.07 \mathrm{~cd}$ & $0.68 \pm 0.16 \mathrm{ab}$ \\
\hline Negative control ${ }^{\mathrm{z}}$ & $0.00 \pm 0.00 \mathrm{~b}$ & $0.00 \pm 0.00 \mathrm{c}$ & $0.00 \pm 0.00 \mathrm{e}$ & $0.00 \pm 0.00 \mathrm{c}$ & $0.00 \pm 0.00 \mathrm{~d}$ & $0.00 \pm 0.00 \mathrm{e}$ \\
\hline Positive control ${ }^{\mathrm{z}}$ & $0.40 \pm 0.09 \mathrm{a}$ & $0.36 \pm 0.08 \mathrm{a}$ & $0.72 \pm 0.12 \mathrm{a}$ & $0.48 \pm 0.20 \mathrm{a}$ & $0.92 \pm 0.05 \mathrm{a}$ & $0.88 \pm 0.10 \mathrm{a}$ \\
\hline$\chi^{2}$ & 25.36 & 26.30 & 50.40 & 41.45 & 57.37 & 52.46 \\
\hline Degrees of freedom & 10 & 10 & 10 & 10 & 10 & 13 \\
\hline$P$ value & 0.0047 & 0.0034 & $<0.0001$ & $<0.0001$ & $<0.0001$ & $<0.0001$ \\
\hline
\end{tabular}

${ }^{\mathrm{x}}$ For each plant (five replications per treatment), five randomly selected flowering dogwood root samples were plated on PARPH-V8 Phytophthora-selective medium to determine the percent recovery of $P$. cinnamomi from root samples.

${ }^{y}$ Treatment means within columns followed by different letters were significantly different $(\alpha=0.05)$.

${ }^{\mathrm{z}}$ Control treatments included the nontreated, inoculated plants (positive control) and nontreated, noninoculated plants (negative control). 
In inoculated plants, disease severity increased with longer flooding duration in both trials $(P \leq 0.0001)$. In trial one, Interface-treated plants had differences in disease severity between 1 day of flooding and 3 or 7 days of flooding ( $P=0.0109$; Fig. 2$)$. No differences were detected among flood durations for any other treatments. In trial two, Actigard-treated plants had higher disease severity at 7 days of flooding than at 1 or 3 days of flooding $(P=0.0099)$, whereas RootShield Plus ${ }^{+}$-treated plants had higher disease severity at 3 or 7 days of flooding than 1 day $(P=0.0208$; Fig. 2). No other differences were detected among flooding durations for any treatment in trial two.

In both trials, a significant interaction between preventive treatments and flooding duration for the percent recovery of $P$. cinnamomi from root samples was detected (trial one: $P=0.0003$; trial two: $P<0.0001)$. In trial one, preventive applications of Pageant, Subdue MAXX, or Tartan had a smaller percent recovery of $P$. cinnamomi from root samples than the positive control at all flooding durations (Table 2). At 1 and 7 days of flooding, the Aliette 50 WG (Aliette), Orkestra, RootShield Plus ${ }^{+}$, and Segovis treatments had a reduced percent recovery of $P$. cinnamomi from root samples compared with the positive control plants (Table 2). Interfacetreated plants had a reduced percent recovery of $P$. cinnamomi from root samples compared with positive control plants flooded 1 or 3 days, and Empress- and MBI-110-treated plants had a smaller percent recovery of $P$. cinnamomi from root samples at 3 and 7 days of flooding (Table 2). Actigard and Signature Xtra had a lower percent recovery of $P$. cinnamomi from root samples than the positive control at 7 days of flooding (Table 2). In trial two, the Empress and Pageant treatments had a lower percent recovery of $P$. cinnamomi from root samples than the positive control at 3 and 7 days of flooding (Table 2). Orkestra- or Interface-treated plants had a lower percent recovery of $P$. cinnamomi from root samples than the positive control at 7 days of flooding, whereas Signature Xtra-treated plants had a lower percent recovery of $P$. cinnamomi at 1 day of flooding (Table 2). Actigard, Aliette, Segovis, and Subdue MAXX had a lower percent recovery of $P$. cinnamomi from root samples than the positive control at 3 days of flooding (Table 2).

Table 4. Mean \pm SE plant growth data of flooded flowering dogwood seedlings preventively treated with fungicides, biofungicides, or host plant defense inducers

\begin{tabular}{|c|c|c|c|c|c|c|c|c|}
\hline \multirow[b]{2}{*}{ Treatment } & \multicolumn{4}{|c|}{ Trial 1} & \multicolumn{4}{|c|}{ Trial 2} \\
\hline & $\begin{array}{l}\text { Plant height } \\
(\mathbf{c m})\end{array}$ & $\begin{array}{l}\text { Plant width } \\
(\mathbf{c m})\end{array}$ & $\begin{array}{l}\text { Plant weight } \\
\text { (g) }\end{array}$ & $\begin{array}{l}\text { Root weight } \\
\text { (g) }\end{array}$ & $\begin{array}{l}\text { Plant height } \\
\text { (cm) }\end{array}$ & $\begin{array}{l}\text { Plant width } \\
(\mathbf{c m})\end{array}$ & $\begin{array}{l}\text { Plant weight } \\
\text { (g) }\end{array}$ & $\begin{array}{c}\text { Root weight } \\
\text { (g) }\end{array}$ \\
\hline Actigard & $22.7 \pm 1.5 \mathrm{bcd}^{\mathrm{y}}$ & $17.2 \pm 1.2 \mathrm{abc}$ & $9.0 \pm 1.4 \mathrm{~cd}$ & $2.2 \pm 0.3 \mathrm{~d}$ & $21.5 \pm 0.9 \mathrm{~b}-\mathrm{e}$ & $10.7 \pm 0.9$ cde & $9.0 \pm 1.1 \mathrm{de}$ & $5.5 \pm 0.7 \mathrm{ef}$ \\
\hline Aliette & $.7 \pm 1.5 \mathrm{a}-\mathrm{d}$ & $17.0 \pm 1.2 \mathrm{bc}$ & $10.1 \pm 1.2 \mathrm{bcd}$ & $3.0 \pm 0.6 \mathrm{bcd}$ & $.6 \pm 0.9 \mathrm{~b}-\mathrm{e}$ & $10.8 \pm 1.1 \mathrm{~b}-\mathrm{e}$ & $9.3 \pm 1.2 \mathrm{de}$ & $5.5 \pm 0.8 \mathrm{ef}$ \\
\hline Empress & $25.6 \pm 1.8 \mathrm{ab}$ & $16.4 \pm 1.1 \mathrm{bc}$ & $12.4 \pm 2.0 \mathrm{abc}$ & $3.8 \pm 0.7 \mathrm{abc}$ & $2.8 \pm 0.7 \mathrm{abc}$ & $11.9 \pm 1.0 \mathrm{~b}-\mathrm{e}$ & $11.4 \pm 1.3 \mathrm{abc}$ & $6.6 \pm 0.9 \mathrm{a}-\mathrm{d}$ \\
\hline Interface & $25.5 \pm 1.6 \mathrm{ab}$ & $18.8 \pm 1.6 \mathrm{ab}$ & $13.2 \pm 2.1 \mathrm{ab}$ & $4.1 \pm 0.7 \mathrm{abc}$ & $21.2 \pm 0.7 \mathrm{~b}-\mathrm{e}$ & $9.5 \pm 1.0 \mathrm{e}$ & $8.3 \pm 1.1 \mathrm{e}$ & $5.1 \pm 0.7 \mathrm{f}$ \\
\hline MBI-110 & $21.4 \pm 1.2 \mathrm{~cd}$ & $15.1 \pm 1.1 \mathrm{c}$ & $7.8 \pm 1.1 \mathrm{~d}$ & $2.7 \pm 0.6 \mathrm{~cd}$ & $22.1 \pm 1.2 \mathrm{a}-\mathrm{d}$ & $11.6 \pm 1.2 \mathrm{~b}-\mathrm{e}$ & $10.5 \pm 1.6 \mathrm{bcd}$ & $6.2 \pm 0.9 \mathrm{~b}-\mathrm{f}$ \\
\hline Orkestra & $25.1 \pm 1.2 a b c$ & $16.6 \pm 1.1 \mathrm{bc}$ & $10.8 \pm 1.3 \mathrm{a}-\mathrm{d}$ & $3.6 \pm 0.6 \mathrm{abc}$ & $22.3 \pm 0.8 \mathrm{abc}$ & $13.4 \pm 1.1 \mathrm{ab}$ & $11.7 \pm 1.3 a b c$ & $7.0 \pm 0.8 \mathrm{abc}$ \\
\hline Pageant & $30.0 \pm 1.3 \mathrm{a}$ & $19.4 \pm 0.7 \mathrm{ab}$ & $13.8 \pm 1.1 \mathrm{a}$ & $4.6 \pm 0.6 \mathrm{a}$ & $20.9 \pm 0.6 \mathrm{cde}$ & $13.0 \pm 1.0 \mathrm{abc}$ & $11.4 \pm 1.2 \mathrm{abc}$ & $6.6 \pm 0.8 \mathrm{a}-\mathrm{d}$ \\
\hline RootShield Plus ${ }^{+}$ & $25.2 \pm 1.2 \mathrm{ab}$ & $15.5 \pm 1.1 \mathrm{c}$ & $9.9 \pm 1.3 \mathrm{bcd}$ & $3.3 \pm 0.6 \mathrm{a}-\mathrm{d}$ & $19.7 \pm 1.0 \mathrm{e}$ & $10.1 \pm 1.0 \mathrm{de}$ & $8.3 \pm 1.3 \mathrm{e}$ & $5.2 \pm 0.8 \mathrm{ef}$ \\
\hline Segovis & $26.4 \pm 1.7 \mathrm{ab}$ & $19.1 \pm 1.4 \mathrm{ab}$ & $13.8 \pm 1.7 \mathrm{a}$ & $4.7 \pm 0.7 \mathrm{a}$ & $23.2 \pm 0.8 \mathrm{ab}$ & $14.0 \pm 0.8 \mathrm{a}$ & $12.3 \pm 1.3 \mathrm{ab}$ & $7.2 \pm 0.9 \mathrm{a}$ \\
\hline Signature Xtra & $23.7 \pm 1.3 \mathrm{a}-\mathrm{d}$ & $19.2 \pm 1.1 \mathrm{ab}$ & $11.8 \pm 1.5 \mathrm{abc}$ & $3.6 \pm 0.6 \mathrm{a}-\mathrm{d}$ & $21.8 \pm 0.6 \mathrm{~b}-\mathrm{e}$ & $12.9 \pm 1.0 \mathrm{abc}$ & $11.7 \pm 1.3 \mathrm{abc}$ & $6.7 \pm 0.9 \mathrm{a}-\mathrm{d}$ \\
\hline Subdue MAXX & $25.6 \pm 1.7 \mathrm{ab}$ & $17.6 \pm 0.9 \mathrm{abc}$ & $11.6 \pm 1.2 \mathrm{abc}$ & $3.9 \pm 0.5 \mathrm{abc}$ & $23.2 \pm 0.9 \mathrm{ab}$ & $13.5 \pm 1.0 \mathrm{a}$ & $12.1 \pm 1.4 \mathrm{ab}$ & $7.0 \pm 0.8 \mathrm{abc}$ \\
\hline Tartan & $19.9 \pm 1.0 \mathrm{~d}$ & $16.4 \pm 1.4 b c$ & $9.8 \pm 1.3 \mathrm{bcd}$ & $3.6 \pm 0.6 \mathrm{abc}$ & $19.9 \pm 0.7 \mathrm{de}$ & $9.8 \pm 0.9 \mathrm{de}$ & $9.7 \pm 1.5 \mathrm{de}$ & $6.0 \pm 0.9 \mathrm{def}$ \\
\hline Negative control $^{\mathrm{z}}$ & $23.6 \pm 1.1 \mathrm{a}-\mathrm{d}$ & $20.3 \pm 1.0 \mathrm{a}$ & $11.9 \pm 1.1 \mathrm{abc}$ & $4.2 \pm 0.4 \mathrm{ab}$ & $24.7 \pm 1.8 \mathrm{a}$ & $14.3 \pm 0.9 \mathrm{a}$ & $13.0 \pm 1.5 \mathrm{a}$ & $7.1 \pm 0.8 \mathrm{ab}$ \\
\hline Positive control $^{\mathrm{z}}$ & $24.9 \pm 1.2 \mathrm{a}-\mathrm{d}$ & $16.3 \pm 1.3 \mathrm{bc}$ & $10.2 \pm 1.0 \mathrm{a}-\mathrm{d}$ & $3.3 \pm 0.5 \mathrm{a}-\mathrm{d}$ & $24.7 \pm 1.0 \mathrm{a}$ & $12.0 \pm 1.0 \mathrm{~b}-\mathrm{e}$ & $9.8 \pm 1.7 \mathrm{de}$ & $6.1 \pm 1.3 \mathrm{def}$ \\
\hline$F$ value & 2.01 & 1.91 & 1.94 & 1.83 & 2.34 & 2.55 & 4.33 & 3.82 \\
\hline Degrees of freedom & 13 & 13 & 13 & 13 & 13 & 13 & 13 & 13 \\
\hline$P$ value & 0.0228 & 0.0317 & 0.0289 & 0.0425 & 0.0079 & 0.0037 & $<0.0001$ & $<0.0001$ \\
\hline
\end{tabular}

y Treatment means within columns followed by different letters were significantly different $(\alpha=0.05)$.

${ }^{\mathrm{z}}$ Control treatments included the nontreated, inoculated plants (positive control) and nontreated, noninoculated plants (negative control).

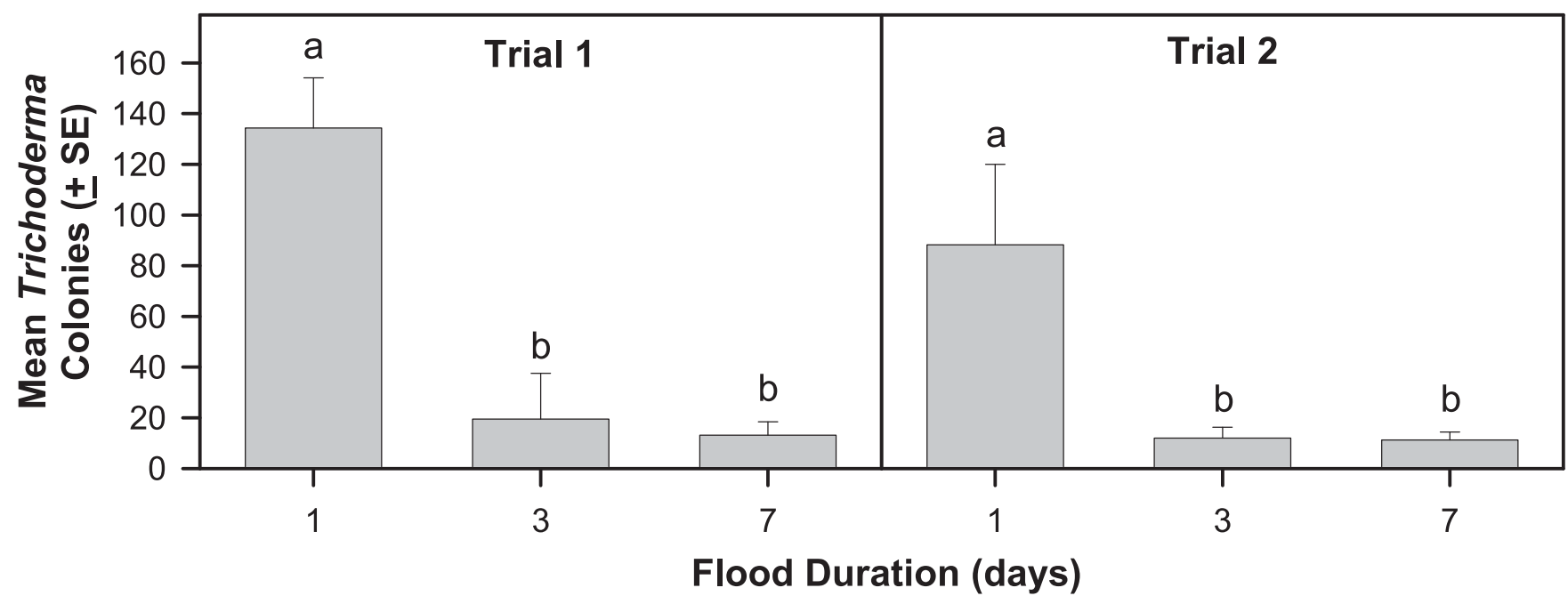

Fig. 4. Trichoderma (mean \pm SE) colony counts on Trichoderma-selective medium at 1,3 , or 7 days of flooding in trials one (left) and two (right). For RootShield Plus ${ }^{+}$-treated plants, undiluted root samples, as well as dilutions of $10^{-2}$ and $10^{-4}$, were plated on Trichoderma-selective medium, and the colonies were counted after 10 days of incubation. Letters above bars represent significant differences in the number of Trichoderma colonies within flooding durations and trials $(\alpha=0.05$, least squares means). 
In both trials, higher Trichoderma root colonization was found at 1 day of flooding than 3 or 7 days of flooding in RootShield Plus ${ }^{+}$-treated plants (trial one: $P=0.0035$; trial two: $P=0.0003$; Fig. 4).

Curative fungicide treatments. No interaction between curative fungicide treatments and flooding duration was detected for plant height (trial one: $P=0.8403$; trial two: $P=0.7156$ ), plant width (trial one: $P=0.6802$; trial two: $P=0.1956$ ), plant weight (trial one: $P=$ 0.3375 ; trial two: $P=0.6246$ ), or root weight (trial one: $P=0.6046$; trial two: $P=0.5104)$. No significant differences were detected among fungicide treatments for plant height, plant width, plant total fresh weight, or root weight compared with the positive control plants in either trial (Table 5).

In trial one, an interaction was detected between curative treatments and flooding duration in disease severity $(P=0.0070)$, so the disease severity data were analyzed separately by flooding duration. Curative treatments of Empress, Orkestra, or Tartan had lower disease severity than the positive control at 1 and 3 days of flooding, while Aliette and Segovis had lower disease severity at 1 day of flooding (Fig. 3). Interface had lower disease severity than the positive control at 3 days of flooding (Fig. 3). No differences in disease severity were detected between curative fungicide treatments and the positive control at 7 days of flooding.

As in trial one, interactions between curative treatments and flooding duration in disease severity were significant for trial two $(P=$ 0.0322). Plants treated with Aliette had lower disease severity than the positive control at all flooding durations, while the Tartan treatment had lower disease severity at 1 and 3 days of flooding (Fig. 3). Pageant and Subdue MAXX only had lower disease severity than the positive control plants flooded 1 day, while Interface- or Segovistreated plants had lower disease severity at 3 days of flooding (Fig. 3).

In inoculated plants, disease severity increased with longer flooding duration in both trials $(P \leq 0.0001)$. In trial one, the Tartan-treated plants had lower disease severity at 1 or 3 days of flooding than 7 days of flooding $(P=0.0100$; Fig. 3$)$. In trial two, plants treated with Interface $(P=0.0176)$, Orkestra $(P=0.0100)$, or Signature $\mathrm{X} \operatorname{tra}(P=0.0244)$ had higher disease severity at 7 days of flooding than 1 or 3 days of flooding (Fig. 3). Significant differences among flooding durations were not detected for any other treatment in either trial.

In both trials with curative fungicide treatments, an interaction was detected between curative treatments and flooding duration in the percentage of infected root samples (trial one: $P=0.0148$; trial two: $P=0.0017)$. At 1 day of flooding, all fungicide treatments in trial one had a reduced percent recovery of $P$. cinnamomi from root samples compared with the positive control (Table 3). The Empress, Signature Xtra, and Subdue MAXX treatments had a smaller percent recovery of $P$. cinnamomi from root samples than the positive control plants flooded 3 days (Table 3). All fungicide treatments, except Empress and Orkestra, had a smaller percent recovery of $P$. cinnamomi from root samples than the positive control plants flooded 7 days (Table 3). In trial two, all fungicide treatments had a reduced percent recovery of $P$. cinnamomi from root samples compared with the positive control at all flooding durations, except Aliette at 3 days of flooding and Subdue MAXX and Tartan at 7 days of flooding (Table 3).

\section{Discussion}

In this study, some fungicides were able to provide effective preventive and curative control of Phytophthora root rot in dogwood seedlings during a simulated flood event. Among fungicide treatments applied preventively or curatively, preventive application of Subdue MAXX was the only treatment that controlled P. cinnamomi at all flooding durations in both trials. Nontreated, inoculated control plants consistently displayed signs of root rot disease (i.e., increased plant mortality, disease severity, and recovery of $P$. cinnamomi from root samples), whereas nontreated, noninoculated control plants did not. Also, plants exposed to longer flooding durations appeared to have greater disease pressure throughout the study. These results are consistent with Wilcox and Mircetich (1985), who found progressively increasing root rot severity as flooding duration increased in two Prunus species that included Prunus mahaleb L. and Prunus avium L. seedlings from 8, 12, 24, and 48 h. In addition, de Silva et al. (1999) found that disease incidence of Phytophthora root rot was higher on Vaccinium corymbosum L. plants flooded weekly or biweekly compared with plants flooded monthly or with no flooding. These results emphasize the crucial value of understanding Phytophthora management during flooding, when the disease is most problematic. Furthermore, cultural practices that improve drainage and minimize plant exposure to flooding will reduce the risk of disease development and augment fungicide efficacy. Although the longer flooding duration increased disease pressure in inoculated plants, flooding alone (i.e., without inoculation with pathogen) was not responsible for plant death or root rot in this study, which is consistent with previous experiments (Ploetz and Schaffer 1989; Wilcox and Mircetich 1985). While disease severity (i.e., percentage of roots with root rot) is useful in research to determine the effects of $P$. cinnamomi on the host plant, nursery producers will be more concerned with overall plant health (i.e., growth, mortality, and aesthetics). In this study, disease severity ratings were directly associated with higher plant mortality, suggesting that the increased disease pressure as a result of flooding will result in economic losses for nursery producers.

Table 5. Mean \pm SE plant growth data of flooded flowering dogwood seedlings curatively treated with fungicides or host plant defense inducers

\begin{tabular}{|c|c|c|c|c|c|c|c|c|}
\hline \multirow[b]{2}{*}{ Treatment } & \multicolumn{4}{|c|}{ Trial 1} & \multicolumn{4}{|c|}{ Trial 2} \\
\hline & $\begin{array}{l}\text { Plant height } \\
\text { (cm) }\end{array}$ & $\begin{array}{l}\text { Plant width } \\
\text { (cm) }\end{array}$ & $\begin{array}{l}\text { Plant weight } \\
\text { (g) }\end{array}$ & $\begin{array}{c}\text { Root weight } \\
\text { (g) }\end{array}$ & $\begin{array}{l}\text { Plant height } \\
\quad(\mathrm{cm})\end{array}$ & $\begin{array}{l}\text { Plant width } \\
\quad(\mathrm{cm})\end{array}$ & $\begin{array}{l}\text { Plant weight } \\
\text { (g) }\end{array}$ & $\begin{array}{c}\text { Root weight } \\
\text { (g) }\end{array}$ \\
\hline Aliette & $22.9 \pm 1.2 \mathrm{a}^{\mathrm{y}}$ & $15.5 \pm 0.9 \mathrm{a}$ & $10.1 \pm 1.6 \mathrm{a}$ & $2.7 \pm 0.5 \mathrm{~cd}$ & $25.2 \pm 1.0 \mathrm{a}$ & $14.4 \pm 0.9 \mathrm{a}$ & $14.8 \pm 1.4 \mathrm{a}$ & $9.0 \pm 1.0 \mathrm{a}$ \\
\hline Empress & $25.3 \pm 1.0 \mathrm{a}$ & $16.0 \pm 1.3 \mathrm{a}$ & $12.9 \pm 1.6 \mathrm{a}$ & $4.3 \pm 0.8 \mathrm{a}$ & $23.7 \pm 1.2 \mathrm{a}$ & $13.9 \pm 1.2 \mathrm{a}$ & $13.6 \pm 1.9 \mathrm{a}$ & $7.1 \pm 1.0 \mathrm{a}$ \\
\hline Interface & $25.2 \pm 1.4 \mathrm{a}$ & $17.2 \pm 1.1 \mathrm{a}$ & $12.3 \pm 1.4 \mathrm{a}$ & $3.9 \pm 0.5 \mathrm{abc}$ & $25.7 \pm 1.4 \mathrm{a}$ & $13.2 \pm 0.9 \mathrm{a}$ & $11.7 \pm 1.0 \mathrm{a}$ & $6.9 \pm 0.6 \mathrm{a}$ \\
\hline Orkestra & $24.9 \pm 1.8 \mathrm{a}$ & $16.5 \pm 1.2 \mathrm{a}$ & $11.2 \pm 1.4 \mathrm{a}$ & $4.1 \pm 0.7 \mathrm{ab}$ & $25.3 \pm 2.1 \mathrm{a}$ & $13.5 \pm 1.2 \mathrm{a}$ & $9.6 \pm 1.0 \mathrm{a}$ & $6.0 \pm 0.7 \mathrm{a}$ \\
\hline Pageant & $25.1 \pm 2.1 \mathrm{a}$ & $16.6 \pm 1.2 \mathrm{a}$ & $10.1 \pm 1.5 \mathrm{a}$ & $3.3 \pm 0.6 \mathrm{a}-\mathrm{d}$ & $24.8 \pm 1.5 \mathrm{a}$ & $14.5 \pm 0.9 \mathrm{a}$ & $14.8 \pm 1.4 \mathrm{a}$ & $8.2 \pm 1.0 \mathrm{a}$ \\
\hline Segovis & $25.0 \pm 1.2 \mathrm{a}$ & $16.6 \pm 1.2 \mathrm{a}$ & $9.1 \pm 1.5 \mathrm{a}$ & $2.8 \pm 0.5 \mathrm{bcd}$ & $27.4 \pm 1.8 \mathrm{a}$ & $13.4 \pm 1.3 \mathrm{a}$ & $12.2 \pm 1.0 \mathrm{a}$ & $7.3 \pm 0.6 \mathrm{a}$ \\
\hline Signature Xtra & $23.8 \pm 1.4 \mathrm{a}$ & $16.1 \pm 1.3 \mathrm{a}$ & $8.8 \pm 1.1 \mathrm{a}$ & $2.6 \pm 0.4 \mathrm{~d}$ & $23.3 \pm 1.4 \mathrm{a}$ & $13.8 \pm 0.8 \mathrm{a}$ & $11.1 \pm 0.7 \mathrm{a}$ & $6.2 \pm 0.5 \mathrm{a}$ \\
\hline Subdue MAXX & $24.2 \pm 1.1 \mathrm{a}$ & $23.5 \pm 6.5 \mathrm{a}$ & $9.9 \pm 1.5 \mathrm{a}$ & $3.5 \pm 0.6 \mathrm{a}-\mathrm{d}$ & $23.9 \pm 1.6 \mathrm{a}$ & $13.9 \pm 1.0 \mathrm{a}$ & $13.0 \pm 1.3 \mathrm{a}$ & $7.4 \pm 0.8 \mathrm{a}$ \\
\hline Tartan & $22.8 \pm 1.4 \mathrm{a}$ & $17.2 \pm 1.2 \mathrm{a}$ & $11.9 \pm 1.5 \mathrm{a}$ & $4.3 \pm 0.7 \mathrm{a}$ & $23.2 \pm 1.3 \mathrm{a}$ & $12.6 \pm 1.4 \mathrm{a}$ & $11.6 \pm 1.7 \mathrm{a}$ & $6.9 \pm 1.0 \mathrm{a}$ \\
\hline Negative control $^{\mathrm{y}}$ & $23.6 \pm 1.1 \mathrm{a}$ & $20.3 \pm 1.0 \mathrm{a}$ & $11.9 \pm 1.1 \mathrm{a}$ & $4.2 \pm 0.4 \mathrm{a}$ & $24.7 \pm 1.8 \mathrm{a}$ & $14.3 \pm 0.9 \mathrm{a}$ & $13.0 \pm 1.5 \mathrm{a}$ & $7.1 \pm 0.8 \mathrm{a}$ \\
\hline Positive control ${ }^{\mathrm{z}}$ & $24.9 \pm 1.2 \mathrm{a}$ & $16.3 \pm 1.3 \mathrm{a}$ & $10.2 \pm 1.0 \mathrm{a}$ & $3.3 \pm 0.5 \mathrm{a}-\mathrm{d}$ & $24.7 \pm 1.0 \mathrm{a}$ & $12.0 \pm 1.0 \mathrm{a}$ & $9.8 \pm 1.7 \mathrm{a}$ & $6.1 \pm 1.3 \mathrm{a}$ \\
\hline$F$ value & 0.46 & 1.12 & 1.23 & 1.95 & 0.63 & 0.59 & 1.69 & 1.06 \\
\hline $\begin{array}{l}\text { Degrees of } \\
\text { freedom }\end{array}$ & 10 & 10 & 10 & 10 & 10 & 10 & 10 & 10 \\
\hline$P$ value & 0.9148 & 0.3514 & 0.2801 & 0.0433 & 0.7958 & 0.8182 & 0.0903 & 0.3986 \\
\hline
\end{tabular}

${ }^{\mathrm{y}}$ Treatment means within columns followed by different letters were significantly different $(\alpha=0.05)$.

${ }^{\mathrm{z}}$ Control treatments included the nontreated, inoculated plants (positive control) and nontreated, noninoculated plants (negative control). 
Mefenoxam (Subdue MAXX) and fosetyl-Al (Aliette, Signature Xtra) are fungicides often recommended for Phytophthora disease management (Chase 1993). Preventively and curatively applied fosetyl-Al had variable effectiveness in this study against $P$. cinnamomi, although fosetyl-Al has demonstrated effectiveness against Phytophthora root rot in other studies (Darvas et al. 1983; Graham and Timmer 2003; Tidball and Linderman 1990). Because fosetyl$\mathrm{Al}$ is a systemic fungicide (Matheron and Matejka 1988), flooding may interfere with the plant's ability to systemically relocate the fungicide through tree tissues. Also, fosetyl-Al's mode of action is partly through host plant defense induction (or systemic acquired resistance) (Molina et al. 1998). Changes in host plant physiology from flooding stress may interfere with the host plant defense induction response to fosetyl-Al. Yasuda et al. (2008) report that the abiotic stress response of hosts can disrupt host signaling associated with systemic acquired resistance. In nonflooded plants grown in soil naturally infested with Phytophthora, Aliette (fosetyl-Al) efficacy was consistent with other fungicide treatments in terms of plant survival, plant total fresh weight, and root weight, but Aliette efficacy measured with these same plant-related factors was reduced with flooding when compared with other fungicide treatments (Matheron and Porchas 2000). Subdue MAXX was the most effective preventively applied treatment in this study, reducing root rot at 1,3, or 7 days of flooding in both trials, but Subdue MAXX was mostly ineffective as a curatively applied treatment. Like fosetyl-Al, mefenoxam (Subdue MAXX) also is a systemic fungicide (Matheron and Matejka 1988), and systemic activity may have been negatively affected in curative treatments that were applied $24 \mathrm{~h}$ after flooding, but less affected when applied as a preventive treatment that was provided 7 days before flooding for fungicide translocation. Mefenoxam and fosetyl-Al are the fungicides often used to manage Phytophthora root rot in nurseries (Erwin and Ribeiro 1996); although mefenoxam was effective when applied preventively, fosetyl-Al had inconsistent effectiveness on flooded plants in our study. Because exclusive mefenoxam treatments in nurseries present the risk of fungicide resistance in $P$. cinnamomi (Darvas and Becker 1984), alternative treatment options should be available for nursery producers. In addition, effective treatment options for Phytophthora root rot are needed for curative treatment of plants after flooding, especially when plants are exposed to prolonged periods of submerged roots.

The strobilurin fungicides (Empress, Interface, Orkestra, Pageant, Tartan) were often effective either preventively or curatively at all flooding durations. Consequently, strobilurin fungicides may be the most effective treatments for Phytophthora management during flooding. All Intrinsic Brand fungicides (Empress, Orkestra, Pageant) and Stressgard fungicides (Interface, Tartan) are labeled as enhancing plant's defensive responses to abiotic stress. Strobilurin fungicides cause changes in stress-related hormones and increase antioxidant enzyme activity in host plants (Chaves et al. 2016; Grossmann and Retzlaff 1997; Wu and Tiedemann 2001), which is associated with flood tolerance (Arbona et al. 2008). Thus, the strobilurins may have been more effective because this study included disease and flooding stress components. More research is needed on how stress-mitigating fungicides affect host physiology to increase stress tolerance, especially on woody ornamental crops.

The two biofungicides, MBI-110 (Bacillus amyloliquefaciens strain F727) and RootShield Plus ${ }^{+}$(T. harzianum Rifai strain T-22 and $T$. virens strain G-41), were both effective as preventively applied treatments at 1 day of flooding, but not at longer flooding durations. In RootShield Plus ${ }^{+}$-treated plants, Trichoderma colony numbers declined with increased flooding duration. Knudsen and Bin (1990) reported that $T$. harzianum Rifai hyphal colonization was negatively affected by wetter soils, possibly because of reduced oxygen availability. Reduced hyphal colonization would result in reduced effectiveness of T. harzianum as a biocontrol agent. However, Smith et al. (1990) found that Trichoderma spp. were effective against $P$. cactorum (Lebert \& Cohn) J. Schrot. in plants exposed to 3 days of flooding. Preventively applied Actigard also was effective at disease reduction only at the shorter (1 day) flooding duration in trial two. Like fosetyl-Al, acibenzolar- $S$-methyl (Actigard) acts through host plant defense induction (Smillie et al. 1989). Therefore, flooding stress may interfere with the host plant induction response to these treatments.

Some fungicides had inconsistent efficacy between trials, possibly owing to different environmental conditions or seasonal timing. Seedling roots in trial two displayed much higher infection levels of the Phytophthora pathogen than in trial one. Although containers were reflooded daily, the potting substrate in trial one (midsummer) dried out quicker than that in trial two (late spring), which may have reduced flooding-induced susceptibility to Phytophthora infection. Also, seedlings in trial one were treated with Concert II for powdery mildew, while plants in trial two were not. Concert II was applied as a foliar spray and is not labeled for treatment of Phytophthora infection. The powdery mildew or the fungicide application may have affected the physiology of dogwood seedlings in trial one and interfered with Phytophthora infection, but the effects would have been uniform across all treatments. In addition, plants in trial two were in the greenhouse for 4 days longer than in trial one, which provided slightly more time for infection and disease development.

Fungicides had reduced efficacy with increased flood duration, probably owing to increased disease pressure and/or negative changes in host physiology from flooding. The efficacy of curatively applied fungicide treatments appeared to be especially affected by longer flooding duration, possibly because of increased disease pressure, increased infection period, and/or reduced uptake of fungicide by the plant. Based on these results, nursery producers should apply fungicides shortly after flooding has ended to ensure optimal fungicide effectiveness. Because the timing of Phytophthora infection was not determined in this study, curative fungicide treatments at shorter flooding durations (e.g., 1 day) may have been applied before the initiation of Phytophthora infection of the young trees. Thus, efficacy seen in 1day flooding treatments may have been from either blocked infection or curative chemical activity or some combination of the two.

Currently, cultural practices that improve drainage are recommended for control of Phytophthora root rot to prevent conditions that promote disease development. However, flooding of plant roots is often difficult to completely prevent in nurseries, so fungicides are often used to supplement cultural practices when necessary. However, nursery producers lack information about effective treatment options for Phytophthora root rot when plants have been flooded, which is precisely when fungicide treatment is required. In this study, many fungicides (Pageant, Segovis, Subdue MAXX) provided adequate control when applied preventively, even after plant roots were submerged experimentally for 7 days. Nonetheless, extreme flood events can be unpredictable, and preventive applications may be unrealistic in some situations. While some fungicides demonstrated curative activity after simulated flood events (e.g., Empress and Tartan at 1 and 3 days of flooding), no curative treatment was effective on plants flooded 7 days in this study. So, further exploration of curative treatments that would be effective after plants have been exposed to prolonged periods of flooding would be valuable to nursery producers. In addition, prompt treatment application after flooding or repeated applications might improve the effectiveness of curative fungicide treatments.

Because of the challenges of preventing flooding in woody ornamental nurseries, environmental stress from excess water will likely continue to periodically favor diseases like Phytophthora root rot that thrive in wet soil conditions. Fungicides can be effective as part of an integrated strategy to manage Phytophthora root rot during flood events. The results of this simulation study indicate that flooding increases disease pressure from Phytophthora root rot, demonstrating the importance of understanding management of Phytophthora infection within the context of flooding. In general, preventive applications were more effective than curative applications for many of the fungicides tested; therefore, superior control of Phytophthora diseases may be achieved if treatments can be applied before extreme flooding events. This study only examined single applications of products, while applications of fungicides with different modes of action in a rotation program would be important for avoiding the development of resistance in the target Phytophthora populations and 
might provide enhanced control of Phytophthora pathogens. Many of the fungicides tested in this study did provide preventive and curative control of Phytophthora infection, and some of these products may be useful management tools for nursery managers. Preventive treatment with mefenoxam could be an excellent option for Phytophthora management programs, as well as the strobilurin fungicides: these compounds showed some efficacy at all flood durations tested in this study, when applied either before or after flooding events.

\section{Acknowledgments}

We thank Debbie Eskandarnia, Md Niamul Kabir, Joseph Lampley, and Terri Simmons (Tennessee State University) for assistance with this project. We thank BASF Corporation, Bayer AG, BioWorks Inc., Marrone Bio Innovations Inc., and Syngenta International AG for donation of products used in trials.

\section{Literature Cited}

Abdul Jaleel, C., Lakshmanan, G. M. A., Gomathinayagam, M., and Panneerselvam, R. 2008. Triadimefon induced salt stress tolerance in Withania somnifera and its relationship to antioxidant defense system. S. Afr. J. Bot. 74:126-132.

Addesso, K., Baysal-Gurel, F., Oliver, J., Ranger, C., and O'Neal, P. 2018. Interaction of a preventative fungicide treatment and root rot pathogen on ambrosia beetle attacks during a simulated flood event. Insects 9:83.

Agresti, A. 2002. Categorical Data Analysis, 2nd ed. Wiley, New York, NY.

Arbona, V., Hossain, Z., López-Climent, M. F., Pérez-Clemente, R. M., and Gómez-Cadenas, A. 2008. Antioxidant enzymatic activity is linked to waterlogging stress tolerance in citrus. Physiol. Plant. 132:452-466.

Benson, D. M. 1985. Fungicides for control of Phytophthora root rot of azalea in landscape beds. Plant Dis. 69:697-699.

Benson, D. M., and Blazich, F. A. 1989. Control of Phytophthora root rot of Rhododendron chapmanii A. Gray with Subdue. J. Environ. Hortic. 7:73-75.

Benson, D. M., and Von Broembsen, S. 2001. Phytophthora root rot and dieback. Pages 52-56 in: Diseases of Ornamentals and Trees in Nurseries. Jones, R. K., and Benson, D. M., eds. American Phytopathological Society, St. Paul, MN.

Bezuidenhout, J. J., Darvas, J. M., and Toerien, J. C. 1987. Chemical control of Phytophthora cinnamomi. S. Afr. Avocado Grow. Assoc. Yearb. 10:106-108.

Blaker, N. S., and MacDonald, J. D. 1981. Predisposing effects of soil moisture extremes on the susceptibility of rhododendron to Phytophthora root and crown rot. Phytopathology 71:831-834.

Chase, A. R. 1993. Review of Fungicides for Control of Phytophthora and Pythium Diseases on Potted Ornamentals. CFREC-Apopka Research Report, RH-93-3. Institute of Food and Agricultural Sciences, Central Florida Research and Education Center, University of Florida, Apopka, FL.

Chaves, A., Pedrosa, E. M. R., Willadino, L., and Cardoso, M. S. O. 2016. Activation of resistance to Meloidogyne incognita in sugarcane treated with pyraclostrobin. Nematoda 3:e052016.

Chung, Y. R., and Hoitink, H. A. J. 1990. Interactions between thermophilic fungi and Trichoderma hamatum in suppression of Rhizoctonia damping-off in a bark compost-amended container medium. Phytopathology 80:73-77.

Conrath, U., Beckers, G. J., Flors, V., García-Agustín, P., Jakab, G., Mauch, F., Newman, M.-A., Pieterse, C. M. J., Poinssot, B., Pozo, M. J., Pugin, A., Scaffrath, U., Ton, J., Wendehenne, D., Zimmerli, L., and Mauch-Mani, B. 2006. Priming: Getting ready for battle. Mol. Plant Microbe Interact. 19:1062-1071.

Darvas, J. M., and Becker, O. 1984. Failure to control Phytophthora cinnamomi and Pythium splendens with metalaxyl after its prolonged use. Citrus Subtrop. Fruit J. 603:9-11.

Darvas, J. M., Toerien, J. C., and Milne, D. L. 1983. Injection of established avocado trees for the effective control of Phytophthora root rot. S. Afr. Avocado Grow. Assoc. Yearb. 6:76-77.

de Silva, A., Patterson, K., Rothrock, C., and McNew, R. 1999. Phytophthora root rot of blueberry increases with frequency of flooding. HortScience 34:693-695.

Donahoo, R. S., and Lamour, K. H. 2008. Characterization of Phytophthora species from leaves of nursery woody ornamentals in Tennessee. HortScience 43:1833-1837.

Duan, C.-H., Riley, M. B., and Jeffers, S. N. 2008. Characterization of Phytophthora cinnamomi populations from ornamental plants in South Carolina, USA. Arch. Phytopathol. Plant Prot. 41:14-30.

Duniway, J. M. 1976. Movement of zoospores of Phytophthora cryptogea in soils. Phytopathology 66:877-882.

Erwin, D. C., and Ribeiro, O. K. 1996. Phytophthora diseases worldwide. APS Press, St. Paul, MN.

Ferguson, A. J., and Jeffers, S. N. 1999. Detecting multiple species of Phytophthora in container mixes from ornamental crop nurseries. Plant Dis. 83:1129-1136.

Graham, J. H., and Timmer, L. W. 2003. Phytophthora diseases of citrus. Pages 250-269 in: Plant Diseases of International Importance, A. Mukhopadhyay, ed. Vol. 3. Prentice-Hall, Upper Saddle River, NJ.

Grossmann, K., and Retzlaff, G. 1997. Bioregulatory effects of the fungicidal strobilurin kresoxim-methyl in wheat (Triticum aestivum). Pestic. Sci. 50:11-20.

Han, S. H., Kang, B. R., Lee, J. H., Lee, S. H., Kim, I. S., Kim, C. H., and Kim, Y. C. 2012. A trifloxystrobin fungicide induces systemic tolerance to abiotic stresses. Plant Pathol. J. 28:101-106.
Harman, G. E. 2006. Overview of mechanisms and uses of Trichoderma spp. Phytopathology 96:190-194.

Herms, S., Seehaus, K., Koehle, H., and Conrath, U. 2002. A strobilurin fungicide enhances the resistance of tobacco against tobacco mosaic virus and Pseudomonas syringae pv tabaci. Plant Physiol. 130:120-127.

Holmes, K. A., and Benson, D. M. 1994. Evaluation of Phytophthora parasitica var. nicotianae for biocontrol of Phytophthora parasitica on Catharanthus roseus. Plant Dis. 78:193-199.

Jacobs, K. A., and Johnson, G. R. 1996. Ornamental cherry tolerance of flooding and Phytophthora root rot. HortScience 31:988-991.

Jeffers, S. N., and Martin, S. B. 1986. Comparison of two media selective for Phytophthora and Pythium species. Plant Dis. 70:1038-1043.

Kloepper, J. W., Ryu, C. M., and Zhang, S. 2004. Induced systemic resistance and promotion of plant growth by Bacillus spp. Phytopathology 94 : $1259-1266$

Knudsen, G. R., and Bin, L. 1990. Effects of temperature, soil moisture, and wheat bran on growth of Trichoderma harzianum from alginate pellets. Phytopathology 80:724-727.

Kozlowski, T. T. 1997. Responses of woody plants to flooding and salinity. Tree Physiol. 17:490.

Kraus, T. E., Fletcher, R. A., Evans, R. C., and Pauls, K. P. 1995. Paclobutrazo enhances tolerance to increased levels of UV-B radiation in soybean (Glycine max) seedlings. Can. J. Bot. 73:797-806.

Lin, K. H. R., Tsou, C. C., Hwang, S. Y., Chen, L. F. O., and Lo, H. F. 2006 Paclobutrazol pre-treatment enhanced flooding tolerance of sweet potato. J. Plant Physiol. 163:750-760

MacDonald, J. D. 1982. Effect of salinity stress on the development of Phytophthora root rot of Chrysanthemum. Phytopathology 72:214-219.

MacDonald, J. D. 1991. Heat stress enhances Phytophthora root rot severity in container-grown chrysanthemums. J. Am. Soc. Hortic. Sci. 116:36-41.

Matheron, M. E., and Matejka, J. C. 1988. Persistence of systemic activity for fungicides applied to citrus trunks to control Phytophthora gummosis. Plant Dis. 72:170-174.

Matheron, M. E., and Porchas, M. 2000. Impact of azoxystrobin, dimethomorph, fluazinam, fosetyl-Al, and metalaxyl on growth, sporulation, and zoospore cyst germination of three Phytophthora spp. Plant Dis. 84:454-458.

Matheron, M. E., and Porchas, M. 2002. Suppression of Phytophthora root and crown rot on pepper plants treated with acibenzolar-S-methyl. Plant Dis. 86: 292-297.

Mircetich, S. M., and Zentmyer, G. A. 1967. Existence of Phytophthora cinnamomi as chlamydospores and oospores in roots and soil. Calif. Avocado Soc. Yearb. 51:117-124.

Molina, A., Hunt, M. D., and Ryals, J. A. 1998. Impaired fungicide activity in plants blocked in disease resistance signal transduction. Plant Cell 10 1903-1914

Ploetz, R. C., and Schaffer, B. 1989. Effects of flooding and Phytophthora root rot on net gas exchange and growth of avocado. Phytopathology 79: 204-208.

Schreier, S. 2013. Diversity Among Isolates of Phytophthora cinnamomi From Ornamental Plants in South Carolina. Master's thesis, Clemson University, Clemson, SC.

Smillie, R., Grant, B. R., and Guest, D. 1989. The mode of action of phosphite Evidence for both direct and indirect modes of action on three Phytophthora spp. in plants. Phytopathology 79:921-926.

Smith, V. L., Wilcox, W. F., and Harman, G. E. 1990. Potential for biological control of Phytophthora root and crown rots of apple by Trichoderma and Gliocladium spp. Phytopathology 80:880-885.

Themann, K., Werres, S., Lüttmann, R., and Diener, H. A. 2002. Observations of Phytophthora spp. in water recirculation systems in commercial hardy ornamental nursery stock. Eur. J. Plant Pathol. 108:337-343.

Tidball, C. J., and Linderman, R. G. 1990. Phytophthora root and stem rot of apple rootstocks from stool beds. Plant Dis. 74:141-146.

Venancio, W. S., Rodrigues, M. A. T., Begliomini, E., and de Souza, N. L. 2003 Physiological effects of strobilurin fungicides on plants. Publ. UEPG Ci. Exatas Terra, Ci. Agr. Eng. Ponta Grossa 9:59-68.

Wilcox, W. F., and Mircetich, S. M. 1985. Effects of flooding duration on the development of Phytophthora root and crown rots of cherry. Phytopathology 75:1451-1455.

Wu, Y. X., and Tiedemann, A. V. 2001. Physiological effects of azoxystrobin and epoxiconazole on senescence and the oxidative status of wheat. Pestic. Biochem. Physiol. 71:1-10.

Yasuda, M., Ishikawa, A., Jikumaru, Y., Seki, M., Umezawa, T., Asami, T., Maruyama-Nakashita, A., Kudo, T., Shinozaki, K., Yoshida, S., and Nakashita, H. 2008. Antagonistic interaction between systemic acquired resistance and the abscisic acid-mediated abiotic stress response in Arabidopsis. Plant Cell 20: 1678-1692.

Zentmyer, G. A. 1983. The world of Phytophthora. Pages 1-8 in: Phytophthora: Its Biology, Taxonomy, Ecology and Pathology. D. C. Erwin, S. BartnickiGarcia, and P. H. Tsao, eds. American Phytopathological Society, St. Paul, $\mathrm{MN}$

Zentmyer, G. A., and Thorn, W. A. 1967. Hosts of Phytophthora cinnamomi. Calif. Avocado Soc. Yearb. 51:177-186. 